\title{
AC 2007-3068: DEVELOPING ENGINEERING CURRICULUM IN AN INTEGRATED KNOWLEDGE ENVIRONMENT
}

Josef Rojter, Victoria University of Tech. 


\title{
Developing Engineering Curriculum in an Integrated Knowledge Environment
}

\begin{abstract}
$\underline{\text { Abstract }}$
Unlike curricula in professional courses such as medicine and law which are focused on specific discourses such as health and justice respectively, engineering curricula at Australian universities lack, by and large, a unifying ideology. In general schools and faculties of engineering at Australian universities have failed to address this issue and resisted calls for change in professional engineering education curricula. This can be attributed to the philosophical perception about engineering, and the introduction of problem-based delivery in engineering schools at Victoria University has opened a door for not only placing greater focus on constructivist learning but also on re-thinking engineering knowledge itself. The reality that many professional engineering graduates not only diffuse across a range of technical areas but also integrate technical material within social, cultural, and environmental frameworks can be embodied into the new course delivery. This paper is concerned with the development of a multi-disciplinary subject syllabus in Chemistry and Materials Technology with an emphasis on, to what Felder and Brent ${ }^{1}$ refer as, independent and contextual knowing. Preliminary student feedback has been fairly mixed with many students feeling more comfortable with the traditional passive and prescriptive approach whereas other students were very positive and indicated that the new approach has been responsible for their decision to continue with their enrolment in engineering.
\end{abstract}

\section{Introduction}

The transformation of professional engineering workplace discourse from one of highly positivist technical in nature to one of social practice has been predicted as an evolutionary process of the professionalization project. Verblen ${ }^{2}$ saw that the rise of technocracy will lead to the engineering profession becoming the guardian of community welfare by ensuring that industry and the economy are kept away from chaos through the path of responsible planning. Galbraith $^{3}$ observed that, since 1945, large scale technological development imposed a new form of power and decision-making in private and public organizations. This essentially gave rise to four major power and decision-making estates: scientists, professions, administrators and politicians. Professions replaced entrepreneurs and professionalism assumed the role of post industrial ideology where it emphasized the essential component of technocracy which involved the translation of knowledge into applied practices, and stressed social service through responsibility to both clients and society.

Galbraith's view implicitly implied that the professionalization project must be accompanied by an acquisition of skills and knowledge of social sciences and humanities as well as the awareness of social and environmental impacts emanating from professional practices. Fawcett and Roberts ${ }^{4}$ observed that the engineering profession will be invisible and marginalized in the public domain if it continues on the path of celebrants of technology without social values. As technological innovations become more common, the wonder of technology, in public eyes, recedes and with it the profession that developed it and services it.

Yet despite the continual rhetoric, in engineering schools, departments and faculties, of meeting needs of industry, there is disquiet ${ }^{5,6}$ concerning skills and knowledge of engineering graduates from Australian universities. The trend towards softer skills can be gauged through 
job advertisements ${ }^{7,8}$ for professional engineers. Since the 1970's the demand for engineering skills has undergone a major paradigm shift from one requiring high technical competence to one requiring social and environmental awareness, good oral and written communication as well as teamwork skills. It is understood that the nature of engineering practice is a multidisciplinary one. It is world-wise and its context is people.

The Australian Science, Technology and Engineering Council identified ${ }^{5}$ the changing landscape of engineering practice. The forces responsible for the change were:

1. Global Integration. The impact of globalization can be viewed as a revolution in the organization of work, production of goods and services. The homogenization of productive activity had meant that engineers had to move their gaze from local perspective to a world-view;

2. Applied Information and Communication Technologies. Professional engineering discourses were now separated by time-zones not time of travel;

3. Environmental Sustainability. Increasing international accountability for sustainable practices meant that professional engineers needed to possess global environmental sensitivities; and

4. Advances in Biological Technologies. Engineering graduates needed broader scientific literacy.

In a similar vein to other professional courses, universities assumed that engineering boundaries were disciplinary ones and as a result the graduate product had little diversity between universities. A graduate in mechanical engineering, for instance, covered the same material in the studies across all universities. The nature of the professional engineering workplaces was more diverse. A report of the Review into Engineering Profession and Engineering Education in Australia concluded ${ }^{5}$ that the professional engineering workplace is not monolithic and observed that professional engineers can be identified as having four major roles in workplaces. These were identified as:

- Engineering/technical managers;

- Technical specialists. Professional engineers key roles in research, technical innovations and as experts;

- System engineers. Professional engineers in these roles are experts in system specification and, in the course of their work, have the ability to integrate the technical and non-technical knowledge domains; and

- Generalist Engineers with broad based technical knowledge enabling them to work across specialist (engineering) boundaries.

Conclusions reached by the committee chaired by Professor Peter Johnson ${ }^{5}$ suggest that there is room in Australia for engineering education providers to provide within each engineering discipline a diversity of courses. To develop new engineering curricula, epistemic notions of professional engineering need to be de-constructed. This is a large project and beyond the scope of this paper. However, it is possible, somewhat, to shape engineering curricula through subject syllabi. This paper is concerned with the development of a subject syllabus in Chemistry and Materials Technology with an emphasis on, what Felder and Brent ${ }^{1}$ to refer as, independent and contextual knowing. In independent knowing students are exposed to the attitude that a significant proportion of engineering knowledge is uncertain and tools of critical thinking and ethical attitudes are required in the decision-making process. Contextual knowledge exposes students to awareness that decisions are not made in a vacuum but may 
have undesirable social, environmental, economic and political ramifications. This is convergent with a development of constructivist, student-centred learning delivery approach culminating in the introduction of PBL (problem-based learning) pedagogies for this subject in the first semester 2007.

\section{Background}

Designing a course syllabus is, at best, a very complex exercise. Though Bloom's hierarchical knowledge taxonomy ${ }^{9}$ was acknowledged for syllabus construction, it had to be adapted in non-linear and non-hierarchical way in which the components of learnt knowledge, comprehension, application, synthesis and evaluation are not sequential but introduced in a convergent way. This was determined not only by design, but also the nature of the subject which shared the same space between disciplines of chemistry and materials science. The objective of the course design was not to produce a seamless transition between these disciplines but to instil a professional way of thinking.

The socio-economic reality of students entering engineering courses at Victoria University not only presented a challenge but offered a new opportunity for course design. A major proportion of students enrolling in engineering at VU come from non-English speaking migrant background in the more socio-economically disadvantaged western and northwestern regions of Melbourne. The minimum admission to engineering at VU, as measured by the ENTER score, on the scale between 10 and 99.95, is at least 10 points below the minimum entry requirements to engineering at other universities in Melbourne. As a comparison the ENTER requirements to engineering courses at the more prestigious Melbourne and Monash universities is between low to high 90's, whereas at Victoria University students are admitted into engineering courses with an ENTER score of 60.

Though a successful completion of a science stream in the final year of secondary education is desirable as an entry point into engineering at university is desirable, the pre-requisite senior high school (year 12) science subjects for entry into engineering courses, at my university, are restricted to successful completion of physics and mathematical methods. The lack of attractiveness of engineering as a course of study combined with the difficulty of attracting high performing secondary school graduates into my university has meant that the entry criteria into engineering at Victoria University (VU) are somewhat relaxed. As a result of diluting the entrance requirements only a minority, between 29 and 34 percent of students, entering engineering courses within the school have completed year 12 chemistry with further 12 to 15 percent of students have only completed year 11 chemistry in their secondary education. Some 10 percent of students, many mature students, undertake preparatory or bridging summer chemistry classes which unlike similar classes in mathematics and physics are not compulsory because it is not a prerequisite entry subject.

\section{The Curriculum}

This subject was organized as a replacement for two second year subjects, each of two 12 week semesters. In the case of mechanical engineering one semester materials subject was replaced by a subject dealing with chemistry/process engineering which also replaced the existing chemistry subject in civil and building engineering courses. The new subject retained 3 hours class contact per week. 
The development of a new subject provided an opportunity to introduce a philosophy of the syllabus design which was to bridge the space between the academic and the practice-based engineering professions. The course did not need to resemble other courses in content or teaching style since there is no acknowledged universal engineering knowledge ${ }^{10}$ or pedagogical approach ${ }^{11}$. In addition to attributes of the traditional syllabus, new attributes were added (table 1).

Table 1. Attributes of the new syllabus

\begin{tabular}{|l|l|}
\hline $\begin{array}{l}\text { Attributes of Traditional } \\
\text { Curriculum /Syllabus }\end{array}$ & Attributes of the New Syllabus \\
\hline Knowing that & Knowing that and knowing how \\
\hline Personal skills & Personal and inter-personal skills \\
\hline Disciplinary skills & Disciplinary and inter-disciplinary skills \\
\hline Intellectual orientation & Intellectual orientation towards practice \\
\hline Knowledge as a process & Knowledge as a process and as a product \\
\hline Concept based & Issue oriented \\
\hline Proposition based learning & Proposition and experiential based learning \\
\hline
\end{tabular}

Table2. Syllabus construct

\begin{tabular}{|c|c|}
\hline $\begin{array}{l}\text { Subject principles } \\
\text { and theory }\end{array}$ & Action and Application \\
\hline $\begin{array}{l}\text { Conservation of } \\
\text { mass and energy }\end{array}$ & $\begin{array}{l}\text { Calculation of mass and energy balances around process units } \\
\text { involving recycle and by-pass streams. }\end{array}$ \\
\hline $\begin{array}{l}\text { Structure of atoms } \\
\text { and atomic bonding }\end{array}$ & $\begin{array}{l}\text { Relationship between the mechanical and physical properties } \\
\text { of solids and the nature of atomic and molecular bonding. }\end{array}$ \\
\hline $\begin{array}{l}\text { Stoichiometric } \\
\text { balances of chemical } \\
\text { reactions. }\end{array}$ & $\begin{array}{l}\text { Calculations around process units involving chemical } \\
\text { reactions such as combustion and smelting processes and } \\
\text { introduction to production of processes such as sulphuric acid, } \\
\text { smelting of ores, setting of cements and calculations of } \\
\text { reactions in the environment. }\end{array}$ \\
\hline $\begin{array}{l}\text { Chemical } \\
\text { equilibrium }\end{array}$ & $\begin{array}{l}\text { Extent of reactions around process units. Acid-base reactions. } \\
\text { Application to processes involving chemical equilibrium. }\end{array}$ \\
\hline $\begin{array}{l}\text { Rate of reactions and } \\
\text { reaction mechanism }\end{array}$ & $\begin{array}{l}\text { Examples from processes. Calculation of process units } \\
\text { involved in the manufacture of polymers and pharmaceuticals. } \\
\text { Illustration of reactions in atmosphere. }\end{array}$ \\
\hline Thermochemistry & $\begin{array}{l}\text { Heat balances around process units. Calculation of process } \\
\text { temperatures for material selection in chemical reactors.Effect } \\
\text { of temperature on the reversibility of reactions. }\end{array}$ \\
\hline Electrochemistry & $\begin{array}{l}\text { Application in the study of production of electricity with } \\
\text { emphasis on batch and fuel batteries. Application to corrosion } \\
\text { and corrosion protection of metals. A study in the production } \\
\text { of aluminium. }\end{array}$ \\
\hline $\begin{array}{l}\text { Studies of } \\
\text { atmospheric and } \\
\text { land pollution. }\end{array}$ & $\begin{array}{l}\text { Calculations involving current issues in fuel technology, } \\
\text { manufacturing industry, agriculture and urban transport. }\end{array}$ \\
\hline Production of steel & Full material and energy balances in production of steels. \\
\hline
\end{tabular}


The syllabus content, of the first part of the subject, was designed on the assumption that students possessed chemical knowledge equivalent to year 9 high-school general science curriculum. This subject was to be delivered in a distinct narrative style which linked theory and principles to material technology and, more importantly, a worldview of engineering discourse. The subject was not to be a stand-alone one but integrated to the rest of the engineering curriculum. A minor objective of this subject was an epistemic one; to make students aware of scientific limitations and distinguish between the scientific and engineering methods. This two-pronged course design is shown in table 2 . The principles and theory provide tools through which technological applications and engineering practice are illustrated.

The chemistry component was introduced in terms of issues, as process engineering, involving energy and mass balances. The material science component was less problematic and though delivered in a traditional way, it required students to participate, in small teams, in both laboratory and library investigative projects.

In 2005, with a prevailing school's stance towards PBL (Problem-based learning) course delivery, there was an opportunity to further fine-tune phenomenological approaches in engineering education. As a result, the subjects of chemistry/process engineering and materials science were to be merged into a single one semester subject with an allocation of 5 hours per week. The course developed and introduced in 2007, further integrated experiential knowledge with social and technological discourses. Greater onus on self learning is to be placed on students working in teams with lecture material providing the theoretical framework. The meeting of student teams to address prescribed problem and issues is to become the central theme of the education vehicle for multi-disciplinary knowledge integration. It is based on a 7 step strategy ${ }^{12}$ in which, once a problem or a project is assigned to a team, the steps are:

- Clarification of concepts and description of the problems;

- Defining the problem. Students need to describe the phenomena which needs to be explained or understood;

- Brainstorming. Using prior knowledge and common sense the team ought to elicit as many explanations of the problem as possible;

- Elaboration of possible explanations. An attempt to construct a coherent theory to be used as a framework to tackle assigned problems;

- Formulation of learning issues for self-learning;

- Filling the gaps of knowledge through self-study; and

- Sharing the findings with the team members.

The course coordinator takes on the role of both a teacher and a team facilitator which may require playing the role of a devil's advocate.

The course is divided into 2 parts, which are:

- Part I. This section deals with both introduction and extension of students' chemical literacy. The students' appreciation of the role chemistry plays in the technical elements of professional engineering practice is conducted trough process engineering case studies such as:

1. Fuel evaluation;

2. Production of nitric acid, ammonia, foodstuff etc; 
3. Greenhouse phenomena and global warming;

4. Evaluation of energy storage;

5. Chemical and electro-chemical deterioration of materials; and

6. Production of cements, aluminium, steel, copper and plastics

The objectives of this part are multi-fold. Their purpose is to exposes the students to the key roles the mass and energy balances play in the analysis of technical problems. It intends to extend students' problem solving skills without reliance on given equations. It also plays a role in the further development of communication, teamwork, and research skills. The final stage of this subject deals with material production and properties that provide a more seamless path to:

- $\quad$ Part II. This section is concerned with the microstructure- property relationship in solid materials. Though some attention is paid to ceramic and polymeric materials, most of the course emphasis is focused on strengthening mechanism of metals and the role phase precipitation play on microstructures and properties of carbon steels and cast irons.

This subject is concerned with the development of professional engineering consciousness and is derived from two major engineering disciplines; chemical engineering and materials engineering. It seeks to develop both knowers, who remember information and can systematically repeat skills, and learners who can create, apply, modify and adapt concepts. The main thrust of this subject is a meta-cognitive one. Meta-cognition is the consciousness of knowledge about knowledge and is based on the assumption that knowing about knowing affects learning. In this subject

- Students will be encouraged to think critically and monitor their understanding; and

- Students will reflect not only on what they know, but on how they know it

Because new knowledge and skills are introduced in this subject, a more traditional pastoraltype educational approach is retained through lectures and tutorials in which formalised/structured knowledge is introduced. The acquisition of new knowledge and the development of cognitive skills in problem identification, "formulation and solution", evaluation will be addressed in both lectures and tutorials. The formalised/structured knowledge will address Bloom's cognitive domains of knowledge, comprehension and (some) application.

The educational components of Open-ended Research, Discovery, Experimentation, and Observation emphasize student-centred learning (table 3 ) and are constructivist in the approach, described by the following:

1. What is learned is a function of the content, context, activity of the learner, and goals of the learner;

2. Students build their own internal frameworks of knowledge upon which they "attach" new ideas; and

3. Cognitive conflict is the stimulus for learning.

The assessment of the subject will consist of three components, these being:

1. Written skills assessment tasks based on lecture and tutorial materials;

2. Open -ended Research and Discovery Projects and the assessment will include:

- Written team report; 
- Oral presentations; and

- Individual reflective journals on investigative work underpinning the reports as a part of student's portfolio.

3. Experimentation and Observation exercises which will be assessed on the basis of:

- Team reports which include the treatment of experimental data and assignment work;

- Individual reflective journals on investigative work underpinning these reports as a part of student's portfolio.

\begin{tabular}{|l|l|}
\hline \multicolumn{2}{|c|}{$\begin{array}{c}\text { Table 3. FORMALISED AND STRUCTURED KNOWLEDGE } \\
\text { (Lectures) }\end{array}$} \\
\hline $\begin{array}{l}\text { Part A: Skills Assessment Task } \\
\text { (1.5 hours) }\end{array}$ & $\begin{array}{c}\text { Part B: Skills Assessment Task } \\
\text { (1.5 hours) }\end{array}$ \\
\hline \multicolumn{2}{|c|}{ Individual portfolios including reflective journal and tutorial tasks } \\
\hline $\begin{array}{l}\text { Part A: Student - Centred } \\
\text { Activities }\end{array}$ & Part B: Student - Centred Activities \\
\hline $\begin{array}{l}\text { Open-ended Research and } \\
\text { Discovery } \\
\text { - Team Report } \\
\text { - Oral Presentation }\end{array}$ & $\begin{array}{l}\text { Experimentation and } \\
\text { Observation }\end{array}$ \\
$\begin{array}{l}\text { Reflection on Ethical, Social } \\
\text { and Environmental Issues }\end{array}$ & $\begin{array}{l}\text { Experimental Techniques } \\
\text { - Literature Research }\end{array}$ \\
Other Issues & - Oral Presentation \\
& • Written Communication \\
\hline
\end{tabular}

The personal reflective journal is a learning tool and is required to be submitted at the end of term as part of the portfolio. The journal will include reflection on issues arising from the course content as well as reflection on what the student has set out to learn, how they have approached their learning, what they have achieved and what they would do differently in the future to improve their learning. The journal may be requested for review by the academic supervisor at any time.

\section{Validation}

The revised course is still at the work-in progress stage and has not as yet been evaluated. However the past course has been evaluated by both students and academic staff.

There is little doubt that the curriculum is relatively dense and it places a great degree of onus on the student. This needed to be done in order to include a component of PBL within the course and widen the students' appreciation of technical engineering discourses. The students' perspective of the subject is an interesting one. In a survey conducted of 8 subjects, by one of my colleagues, on subject quality between 1996-1998 indicated that students rated this subject as among two of the most demanding and difficult subjects though interestingly students also rated the subject as the most interesting and most satisfying. In an informal Student Educational Satisfaction (SES) survey, conducted in 2005, the two questions concerning work demands placed on the student and satisfaction and enthusiasm aroused by the subject gave 
scores of 4.0 and 4.1 on the Likert scale ranging from 1-5.

I have, as well as for other subjects, encouraged students' evaluation of teaching and subject content using a simple Hildebrand's model ${ }^{13}$ with two extended statements. Students' evaluation used Likert's scale ranging from strongly agree (5 points) to strongly disagree (1 point). The average scores are shown in table 4.

Table 4. Subject Assessment

\begin{tabular}{|l|l|l|l|l|l|l|l|l|}
\hline \multirow{2}{*}{ Statement } & \multicolumn{6}{|c|}{ Year of Assessment and average score } \\
\cline { 2 - 10 } & 1997 & 1998 & 1999 & 2000 & 2001 & 2003 & 2004 & 2005 \\
\hline $\begin{array}{l}\text { The lecturer has a good } \\
\text { command of the subject. }\end{array}$ & 4.5 & 4.3 & 4.7 & 4.6 & 4.5 & 4.7 & 4.4 & 4.5 \\
\hline The subject objectives are clear. & 3.8 & 3.9 & 4.2 & 4.1 & 3.8 & 4.4 & 4.0 & 4.2 \\
\hline $\begin{array}{l}\text { Lecturer interacts well with the } \\
\text { class. }\end{array}$ & 4.0 & 3.8 & 4.3 & 4.3 & 4.3 & 4.1 & 4.1 & 4.3 \\
\hline $\begin{array}{l}\text { Lecturer is accessible for } \\
\text { individual consultations. }\end{array}$ & 4.1 & 3.9 & 3.9 & 3.8 & 4.0 & 3.8 & 3.9 & 4.0 \\
\hline $\begin{array}{l}\text { Lecturer arouses curiosity in the } \\
\text { subject. }\end{array}$ & 4.0 & 3.8 & 4.4 & 4.1 & 4.0 & 3.6 & 4.0 & 4.0 \\
\hline $\begin{array}{l}\text { The subject widens the scope of } \\
\text { engineering knowledge. }\end{array}$ & 3.8 & 3.9 & 4.2 & 4.3 & 4.1 & 3.9 & 4.5 & 4.1 \\
\hline $\begin{array}{l}\text { The subject is satisfying and } \\
\text { would recommend to others. }\end{array}$ & 4.1 & 4.2 & 4.0 & 4.0 & 4.3 & 4.0 & 4.2 & 4.1 \\
\hline
\end{tabular}

Though the first 5 statements, in table 4 above, evaluate the teacher performance what is interesting is that in the last two statements the students are very positive about this subject and felt that it enhanced their engineering literacy and the understanding of the physical world around them.

Unlike fundamental sciences such as physics and mathematics, the chemical science course did not assume prior high school knowledge in this subject and, unlike other engineering sciences, it does not rely on physical science pre-requisites. For most students, like engineering design, this subject represented new knowledge, and an introduction to a different way of thinking inclusive of open-ended problems and solutions. However unlike engineering design, this subject was also concerned in establishing new directions of information processing, particularly with concept attainment, which Bruner ${ }^{14}$ defines concept attainment as a way of organizing knowledge that leads to concept development and synectics. Gordon and Pore ${ }^{15}$ observed that synectics represented collaborative group processing of knowledge that promoted synergy in development of critical thinking skills. The effect of previous knowledge of chemistry on student performances are shown in tables 5 and 6. Table 5 compares student performances, with different preparations, when the subject was offered in the first semester at the second year level and table 6 deals with student performance when the subject was transferred into first semester of first year of the course.

Table 5 illustrates that there was little disparity in the subject performance between students who studied chemistry in secondary schools at the highest levels and those who have not studied chemistry before. The pass rates varied between 75 and just above 80 percent, well above the pass rates of mathematics and other engineering science subjects at second year level. The yearly variations in pass rates occurred to the variation of the mix of students 
between mechanical, civil, building and architectural students.

Table 5. Comparisons of student performance in second year.

\begin{tabular}{|c|c|c|c|c|c|c|c|c|}
\hline \multirow[t]{2}{*}{ Preparation } & \multirow{2}{*}{$\begin{array}{l}\text { Year of } \\
\text { Survey }\end{array}$} & \multicolumn{6}{|c|}{ GRADES (\% of student population) } & \multirow{2}{*}{$\begin{array}{l}\text { Av. } \\
\text { Score } \\
(\%)\end{array}$} \\
\hline & & HD & D & $\mathbf{C}$ & $\mathbf{P}$ & N1 & $\mathbf{N 2}$ & \\
\hline \multirow{3}{*}{ Year 12} & 2000 & 12.8 & 13.1 & 19.6 & 26.1 & 7.5 & 20.9 & 60.0 \\
\hline & 2001 & 13.2 & 15.2 & 18.9 & 26.1 & 8.1 & 18.5 & 61.2 \\
\hline & 2002 & 13.1 & 14.9 & 24.1 & 29.2 & 8.1 & 10.6 & 63.2 \\
\hline \multirow{3}{*}{ Year 11} & 2000 & 10.1 & 12.8 & 19.9 & 27.1 & 7.9 & 21.4 & 57.8 \\
\hline & 2001 & 13.1 & 12.8 & 21.6 & 27.6 & 7.9 & 16.9 & 59.5 \\
\hline & 2002 & 13.6 & 14.1 & 22.4 & 26.9 & 8.1 & 14.9 & 60.5 \\
\hline \multirow{3}{*}{ Bridging } & 2000 & 8.4 & 14.0 & 23.1 & 32.1 & 5.9 & 16.5 & 58.0 \\
\hline & 2001 & 10.7 & 13.6 & 23.6 & 31.8 & 9.5 & 10.8 & 58.1 \\
\hline & 2002 & 10.7 & 12.9 & 23.1 & 30.9 & 8.6 & 13.8 & 58.0 \\
\hline \multirow{3}{*}{ None } & 2000 & 9.9 & 10.0 & 26.1 & 33.0 & 8.0 & 13.0 & 57.6 \\
\hline & 2001 & 11.1 & 10.0 & 24.3 & 31.8 & 8.6 & 14.2 & 57.7 \\
\hline & 2002 & 10.0 & 9.9 & 24.3 & 32.1 & 9.9 & 13.5 & 56.7 \\
\hline
\end{tabular}

HD $($ High Distinction $)=80+\%, \mathrm{D}($ Distinction $)=70 \%-79 \%, \mathrm{C}($ Credit $)=60 \%-69 \%$, $\mathrm{P}($ Pass $)=50 \%-59 \%, \mathrm{~N} 1($ Fail $)=40 \%-49 \%$, N2 $($ Fail $)<39 \%$

Table 6. Comparisons of student performance in the first year.

\begin{tabular}{|c|c|c|c|c|c|c|c|c|}
\hline \multirow[t]{2}{*}{ Preparation } & \multirow{2}{*}{$\begin{array}{l}\text { Year of } \\
\text { Survey }\end{array}$} & \multicolumn{6}{|c|}{ GRADES (\% of student population) } & \multirow{2}{*}{\begin{tabular}{|l|} 
Av. \\
Score \\
$(\%)$
\end{tabular}} \\
\hline & & HD & D & $\mathrm{C}$ & $\mathbf{P}$ & N1 & $\mathbf{N} 2$ & \\
\hline \multirow{3}{*}{ Year 12} & 2003 & 8.8 & 8.1 & 25.2 & 31.2 & 4.0 & 26.7 & 58.2 \\
\hline & 2004 & 11.5 & 10.6 & 34.6 & 25.0 & 3.0 & 15.3 & 59.1 \\
\hline & 2005 & 12.2 & 14.6 & 29.2 & 26.8 & 4.9 & 12.2 & 61.1 \\
\hline \multirow{3}{*}{ Year 11} & 2003 & 7.2 & 7.2 & 8.6 & 22.8 & 13.2 & 41.0 & 49.1 \\
\hline & 2004 & 8.8 & 7.2 & 11.2 & 26.3 & 19.0 & 27.5 & 53.2 \\
\hline & 2005 & 10.5 & 0.0 & 10.5 & 31.6 & 26.3 & 21.1 & 54.4 \\
\hline \multirow{3}{*}{ Bridging } & 2003 & 16.2 & 3.6 & 11.2 & 32.1 & 12.5 & 24.4 & 50.1 \\
\hline & 2004 & 14.1 & 1.5 & 12.2 & 34.1 & 10.6 & 27.5 & 51.1 \\
\hline & 2005 & 22.2 & 0.0 & 11.1 & 33.3 & 11.1 & 22.2 & 50.0 \\
\hline \multirow{3}{*}{ None } & 2003 & 3.5 & 1.8 & 11.5 & 31.6 & 1.6 & 50.3 & 42.2 \\
\hline & 2004 & 3.6 & 1.8 & 10.7 & 31.6 & 0.0 & 52.3 & 43.1 \\
\hline & 2005 & 3.9 & 2.0 & 11.8 & 33.3 & 3.9 & 45.1 & 43.7 \\
\hline
\end{tabular}

HD $($ High Distinction $)=80+\%, \mathrm{D}($ Distinction $)=70 \%-79 \%, \mathrm{C}($ Credit $)=60 \%-69 \%$, $\mathrm{P}($ Pass $)=50 \%-59 \%, \mathrm{~N} 1($ Fail $)=40 \%-49 \%$, N2 $($ Fail $)<39 \%$

The transfer of the course into first year has not proved to be a positive thing. A variation of performance in the subject between students who have completed year 12 chemistry and those who have studied less or no chemistry in secondary schools is observed in table 6 . The results of students who undertook bridging courses are distorted by the small population of students and the mix of students. Some students who enrolled in the summer bridging course had completed year 11 chemistry, others have not done chemistry before and these included many 
mature students who, by-and-large, were responsible for the relatively high proportion of high distinctions.

The comparisons between tables 5 and 6 indicate that a level of maturity was required to tackle this subject. Nevertheless table 6 shows that students without prior knowledge but willingness to study can successfully complete this subject. In fact the overall pass rate for this subject was higher than pass rates in both physics and mathematics which required year 12 equivalent preparation as a pre-requisite for the course.

\section{Conclusion}

Unlike other professional courses, engineering at Australian universities has been, by and large, treated as an academic discipline of science. Its role as a scientific discipline is firmly anchored in the public mind and has weathered recommendations for transformation towards market and societal-oriented knowledge. This is understandable since engineering grew out of the enlightement notions of scientific practices which were linear and underpinned by a set of methods with the belief that each problem solved ameliorates the human condition because there is one less problem to solve.

Yet changes in engineering are necessary since engineering is not a scientific discipline. It is different from science because of it is multi-disciplinary and like artit explains rather than states meanings. It owes as much to a critical theory which takes place at hidden coercions of concrete contradictions in the established worldview ${ }^{16}$. Green ${ }^{17}$ observes that like other professions, the engineering profession possesses tacit knowledge which cannot be readily converted to formal and abstract knowledge found in sciences.

Though the transformation of universities as the post-modernist philosopher and critic Lyotard ${ }^{18}$ observed from critical social institutions to ones that are utilitarian and have become an arm of government's social and economic policies can be attributed to the substitution of knowledge based seeking truth by knowledge based on application has been a reality, the transformation of engineering curriculum has not accompanied institutional transformations. Despite the many recommendations by formally instituted inquiries into engineering profession and education, the changes in engineering education have been sublime and not concrete. The Changes in engineering curricula are difficult to implement because ideas of different engineering domain are contrary to academic beliefs often shaped by disciplinary (scientific) research.

It is nevertheless possible to tinker with the engineering curriculum at the subject level. The subject discussed in this paper provided such an opportunity to introduce new material, in a different way, for which the majority of students had no pre-requisites. The subject material was introduced in a form that confronted students' notions of knowledge as being linear and consisting of collection of facts ${ }^{20}$. The objective of the subject was to arouse student curiosity and therefore improve the quality of active learning. This was done by exposing students to the fact that professional engineering practice, like other professional practices, is non-linear, open-ended and messy. This approach, as shown by student response and evaluation of the subject, seem to be successful in enhancing student participation and active role in students absorbing new knowledge. It is hoped that further movement towards student centred learning will aid towards a professionalization of the engineering curriculum. 


\section{References}

1. Felder, R.M., and Brent, R. (2004). “The Intellectual Development of Science and Engineering," Journal of Engineering Education,, 93(4) pp269-273.

2. Veblen, T. (1963). The Engineers and the Price System, New York: Harcourt Brace.

3. Galbraith, J.K. (1967). The New Industrial State, Boston: Houghton Mifflin.

4. Fawcett, A., and Roberts, P. (2001). “ The Institution of Engineers Australia- At the Turn, Remaking for Relevance," Transactions of Multi-disciplinary Engineering, vol.25, pp 51-63.

5. Johnson, P (1996). Changing the Culture:Engineering Education into the Future, Canberra: The Institution of Engineers, Australia.

6. ASTEC (1996). Matching Science and Technology to Future Needs- Key Issues for Australia to 2010, Canberra.: Australian Science and Technology Council.

7. Clehouse, R.E. (1998). "Critical Issues Facing Engineering," in Young, W.H. Continuing Professional Education in Transition-Visions for Professions and New Strategies for Lifelong Learning, Malabar, Florida: Krieger Publishing Company, pp. 307-324.

8. Rojter, J. (2004). "The role of humanities and social sciences in engineering practice and engineering education," Proceedings of the Annual AAEEConference, Towoomba: Australasian Association for Engineering Education.

9. Bloom, B.S (1956). Taxonomy of Educational Objectives: Handbook 1, Cognitive Domain, New York: Longman.

10. Turns, J., Altman, C.J., Adams, S.R., and Barker, T. (2005). "Research on Engineering Student Knowing: Trends and Opportunities," Journal of Engineering Education, 94 (1), pp. 27-40.

11. Holmgren, C., and From, J. (2005). "Taylorism of the Mind: entrepreneurship education from a perspective of educational research," European Educational Research Journal, 4 (4), pp382-390.

12. Moust, J.H.C., Van Berkel, M.J.H., and Schmidt, G.H. (2005). "Signs of erosion: Reflections on three decades of problem-based learning at Maastricht University," Higher Education 50, pp. 665-683.

13. Hilderbrand, M (1973). "The character and skills of the effective professor", Journal of Higher Education, 44 (4), pp.41-50.

14. Bruner, J (1961). The Process of Education, Cambridge, Mass: Harvard University Press.

15. Gordon, W.W.J., and Pore, T (1976). The Art of the Possible, Cambridge, Mass: Porpoise Books.

16. Paringer, W.A. (1990). John Dewey and the Paradox of Liberal Reform, Albany: State University of New York.

17. Green, M. (2000). Educating the New Engineer," Trans. Of Multi-Disciplinary Engineering, vol.6, pp. 3950.

18. Lyotard, J-F (1984). The Postmodern Condition: a report on knowledge, Manchester: Manchester University Press.

19. Barnett, R., Parry. G., and Coate, K (2001). "Conceptualising Curriculum Change", Teaching in Higher Education, 6 (4), pp435-449.

20. Paulsen, M.B., and Wells, C.T (1998). "Domain differences in the epistemological beliefs of college students", Research in Higher Education, 39(4), pp365-384. 